\title{
Patient Satisfaction after Total Knee Arthroplasty
}

\author{
Young-Joon Choi, MD and Ho Jong Ra, MD \\ Department of Orthopedic Surgery, Gangneung Asan Hospital, Ulsan University College of Medicine, Gangneung, Korea
}

Total knee arthroplasty (TKA) is one of the most successful and effective surgical options to reduce pain and restore function for patients with severe osteoarthritis. The purpose of this article was to review and summarize the recent literatures regarding patient satisfaction after TKA and to analyze the various factors associated with patient dissatisfaction after TKA. Patient satisfaction is one of the many patient-reported outcome measures (PROMs). Patient satisfaction can be evaluated from two categories, determinants of satisfaction and components of satisfaction. The former have been described as all of the patient-related factors including age, gender, personality, patient expectations, medical and psychiatric comorbidity, patient's diagnosis leading to TKA and severity of arthropathy. The latter are all of the processes and technical aspects of TKA, ranging from the anesthetic and surgical factors, type of implants and postoperative rehabilitations. The surgeon- and patient-reported outcomes have been shown to be disparate occasionally. Among various factors that contribute to patient satisfaction, some factors can be managed by the surgeon, which should be improved through continuous research. Furthermore, extensive discussion and explanation before surgery will reduce patient dissatisfaction after TKA.

Keywords: Knee, Osteoarthritis, Arthroplasty, Satisfaction

\section{Introduction}

Total knee arthroplasty (TKA) is one of the most effective surgical interventions for pain relief and functional recovery in patients with advanced degenerative arthritis or rheumatoid arthritis $^{1)}$. Aging of the society has led to increases in the prevalence of arthritis and the incidence of TKA for end-stage arthritis. Accordingly, the outcomes of TKA have been reported in a multitude of studies, most of which being centered on the outcomes measured from the surgeon's perspective, such as the implant survivorship, postoperative range of motion (ROM), and radiographic improvement However, it is not uncommon to encounter

Received April 16, 2015; Revised August 12, 2015;

Accepted September 12, 2015

Correspondence to: Ho Jong Ra, MD

Department of Orthopedic Surgery, Gangneung Asan Hospital, Ulsan University College of Medicine, 38 Bangdong-gil, Gangneung, 25440, Korea

Tel: +82-33-610-3244, Fax: +82-33-641-8050

E-mail: os_rahj@naver.com

This is an Open Access article distributed under the terms of the Creative Commons Attribution Non-Commercial License (http://creativecommons.org/licenses/by-nc/4.0/) which permits unrestricted non-commercial use, distribution, and reproduction in any medium, provided the original work is properly cited. a situation where a treatment rated successful from the surgeon's perspective fails to deliver patient satisfaction. In general, patients tend to be less satisfied with treatment outcomes than does the surgeon ${ }^{2,3)}$. Harris et al. ${ }^{4)}$ reported there was a discordance between patient satisfaction and surgeon satisfaction (90.3\% vs. 94.5\%) in 331 TKA patients at 12 months after surgery.

They attributed this mainly to the preoperative level of patient expectation and development of complications. In an effort to overcome the discrepancy in patient-surgeon satisfaction, patient-reported outcome measures (PROMs) designed for the objective assessment of patient satisfaction with a treatment have been devised ${ }^{2,5,6)}$.

In this review article, we will summarize recent literatures regarding patient satisfaction after TKA, describe currently available PROMs, and investigate various causes and predictors of patient dissatisfaction after TKA.

\section{Patient Satisfaction}

The concept of patient satisfaction was first defined by Ware et al. ${ }^{7)}$ in 1873. Patient satisfaction after TKA can be associated with patients' expectations, pain relief, and functional improvement. Lau et al. ${ }^{2)}$ suggested that following two perspectives, internal determinants and external components, should be considered in the evaluation of patient satisfaction. The former refers to 
patient-dependent factors, such as age and expectations, whereas the latter indicates patient-independent factors, such as hospital environment and surgical technique. Patient satisfaction after TKA has been described as ranging from $75 \%$ to $92 \%$. Based on a review of the Swedish Knee Arthroplasty Registry, Dunbar et al. ${ }^{8)}$ reported that $17 \%$ of the patients were not satisfied with the outcome of TKA. Schulze and Scharf ${ }^{9)}$ conducted a systematic review of studies on patient satisfaction after TKA assessed between 1990-1999 and 2000-2012, which showed patient satisfaction increased from $81.2 \%$ in the former decade to $85 \%$ in the latter 13 years. Baker et al. ${ }^{10)}$ reviewed the data from the National Joint Registry for England and Wales: 71\% of the patients perceived improvement of knee symptoms, but only $22 \%$ rated the results as 'excellent'. Kim et al. ${ }^{11)}$ reported that in spite of the clear evidence of improvement after TKA in terms of restoration of daily living activities and pain relief, patient satisfaction level was moderate.

\section{Patient Satisfaction Measurement Tools}

The Knee Society Clinical Rating System (Appendix 1) has been widely used since 1989 as a relatively objective scoring system for the assessment of TKA outcomes in spite of deficiencies in the items for patient satisfaction assessment. The new Knee Society Knee Scoring System was introduced in 2011 to incorporate patient-reported outcome assessment scales (satisfaction, expectations, and physical activities) in the rating system ${ }^{12}$ (Appendix 2). Other popular PROMs include the 36-item Short Form Health Survey (SF-36) ${ }^{13}$, the 12-item Short Form Health Survey (SF-12), the Western Ontario and McMaster Universities Arthritis Index $(\text { WOMAC })^{14)}$, the Knee injury and Osteoarthritis Outcome Score $(\mathrm{KOOS})^{15)}$, and the Oxford knee score (OKS) ${ }^{16)}$ (Appendix 3-7). The SF-36 is a measure of general health state including emotional and mental health. The WOMAC is widely used as a diseasespecific measure in patients with osteoarthritis to evaluate the efficacy of surgical and non-surgical interventions. The KOOS is a self-administered questionnaire designed to assess the outcome of treatment of anterior cruciate ligament injuries and meniscus injuries. The OKS has been recognized as one of the most effective disease-specific measures for patients with degenerative arthritis, which correlates strongly with pain but less with postoperative functioning ${ }^{17)}$. Among the items that are included in these PROMs, pain, mobility, physical function, and mental health are known as primary factors influencing patient satisfaction.

\section{Patient Dissatisfaction: Causes and Types}

The most common causes of patient dissatisfaction include residual pain and limited function; however, pain relief and functional recovery have demonstrated no significant correlation in many studies. Judge et al. ${ }^{18)}$ reported that postoperative pain was associated with the preoperative diagnosis, such as rheumatoid arthritis, and patient's mental status, such as anxiety and depression, whereas functional recovery was affected by age and gender. Scott et al. ${ }^{19)}$ noted that a high percent of patients were not satisfied with their ability to kneel, squat, and climb stairs after TKA. According to Ghomrawi et al. ${ }^{20)}$, patients with expectations of high-level activities and extreme ROM reported dissatisfaction after TKA. In a study by Parvizi et al. ${ }^{21}$, $89 \%$ of the patients were satisfied with their ability to perform daily living activities and $91 \%$ were satisfied in terms of pain relief. In the study, however, only $66 \%$ reported their knees felt normal, $33 \%$ had lingering pain, $41 \%$ suffered from stiffness, $33 \%$ complained of bothering noise, swelling, or tightness, and difficulty in getting in and out of a car, getting up and down from a chair, and climbing up and down stairs were reported in $38 \%, 31 \%$, and $54 \%$, respectively.

\section{Internal Determinants of Patient Satisfaction}

The possible internal determinants of patient satisfaction include age, gender, patient's personality, patient's expectations, physical and psychological comorbidities, diagnosis for TKA, and the severity of arthropathy.

\section{1) Age}

There is still no consensus on the influence of age on patient satisfaction. Patients were more satisfied with the outcome of TKA when they were 60 years or younger in a study by Noble et al. ${ }^{22}$. According to Scott et al. ${ }^{19)}$, younger patients tended to report their expectations were met after surgery, and thus obtained greater satisfaction with the treatment outcomes. On the other hand, Williams et al. ${ }^{23)}$ reported that patient satisfaction was significantly low among patients less than 55 years of age. Parvizi et al. ${ }^{21)}$ described that residual symptoms and functional deficits were more prevalent in younger patients. Von Keudell et al. ${ }^{24)}$ documented that satisfaction with postoperative pain, ROM, and kneeling was higher after unicompartmental knee arthroplasty in patients less than 55 years of age, whereas TKA provided greater satisfaction in patients more than 65 years of age. Therefore, it is difficult to determine whether age is predictive of the outcome of TKA. It appears that biological age, rather than chronological age, has a greater role in functional recovery after TKA.

\section{2) Gender}

Residual pain and stiffness are likely to be more prevalent in 
female TKA patients ${ }^{25,26)}$. However, it has not been sufficiently established as to whether gender is a predictive factor of patient satisfaction.

\section{3) Patient's personality}

Gong and Dong ${ }^{27)}$ retrospectively investigated the relationship between the outcomes of TKA and patient's personality classified into 4 types: patients with extroverted personality were more satisfied than those with introverted or anxious personality after TKA. In our opinion, however, the influence of personality on the outcome of TKA is not straightforward to determine due to the difficulty of categorizing various human personalities.

\section{4) Patient's expectations}

The degree to which patients' expectations are met can be an important predictor of patient satisfaction. Bourne et al. ${ }^{28)}$ reported that unmet expectations were the strongest predictor of dissatisfaction after TKA. Scott et al. ${ }^{29}$ also showed a close correlation between patients' expectations and their satisfaction. However, patient's expectations tend to be higher than the surgeon's ${ }^{4,20)}$. Initially after TKA, patients are mostly concerned with pain relief. In the long-term, however, they expect to recover symptomfree functions for activities that personally matter to themselves. While surgeons relate to the patients' long-term goals, they are well aware that such expectations may not be fulfilled ${ }^{30}$. Therefore, it is an important role of the surgeon to inform the patient of the possibility of unmet expectations. Contrary to these results, recent systemic reviews by Haanstra et al. ${ }^{31)}$ and Culliton et al. ${ }^{32}$ have shown that there is no notable association between patient's expectations and postoperative satisfaction, suggesting the need for more objective measures of assessment.

\section{5) Comorbidities}

Comorbidities have been established as a predictor of patient dissatisfaction after $\mathrm{TKA}^{33)}$ in a multitude of studies. Scott et al. ${ }^{29)}$ demonstrated that preoperative back pain or pain in the other joints was significantly associated with postoperative dissatisfaction. Singh and Lewallen ${ }^{34)}$ reported that postoperative pain was severer in patients with medical or psychological comorbidities. Clement and Burnett ${ }^{35)}$ showed generic physical health was related to patient satisfaction. Vissers et al. ${ }^{36)}$ observed patients with low preoperative mental health based on the SF-12 and SF36 scores obtained poor outcomes in terms of pain relief and functional improvement. Wylde et al. ${ }^{37)}$ reported that patients with medical comorbidities were more likely to experience pain or functional disability after TKA. Fisher et al. ${ }^{26)}$ noted a higher incidence of limited mobility after TKA in patients with diabetes or pulmonary disease. Although the prevalence of anxiety and depressive symptoms that are high in patients scheduled for TKA decreases significantly after surgery ${ }^{38)}$, these patients tend to have lower satisfaction after surgery than those without preoperative comorbidities $^{18,37,38)}$. On the other hand, some studies have shown that preoperative depression does not affect postoperative func$\operatorname{tion}^{36)}$. Rather, patients with preoperative depression appear to obtain higher level of satisfaction after TKA than those without ${ }^{39)}$.

\section{6) Diagnosis for TKA}

Rheumatoid arthritis patients have been reported to have greater satisfaction than patients with other indications for surgery ${ }^{18)}$. This can be attributed either to 1) the fact that the most important expectation among rheumatoid arthritis patients is pain relief, whereas patients with other diseases are more concerned with functional improvement ${ }^{40)}$ or to 2 ) the relatively low expectation among patients with rheumatoid arthritis ${ }^{41)}$.

\section{7) Severity of arthropathy}

Bourne et al. ${ }^{28)}$ reported the postoperative satisfaction was low among patients who complained of severe pain while resting, lying in a bed, or sitting on a chair before surgery. On the other hand, Maratt et al. ${ }^{42)}$ described that patients with severe pain or dysfunction before surgery were more likely to be satisfied after surgery as long as the preoperative symptoms did not cause severe disruption in health-related quality of life. Kim et al. ${ }^{43)}$ reported patient's dissatisfaction with TKA was associated with poor preoperative WOMAC score, indicating that end-stage arthritis patients are likely to have a low level of satisfaction. However, Schnurr et al. ${ }^{44)}$ have recently shown that patients with mild or moderate osteoarthritis are at an elevated risk for dissatisfaction after TKA. In a study by Polkowski et al. ${ }^{45}$, the incidence of unexplained pain after TKA was higher in patients with earlystage osteoarthritis before surgery.

\section{8) Other factors}

Fisher et al. ${ }^{26)}$ reported high body mass index, previous history of knee surgery, and disabilities as patient factors that could contribute to poor satisfaction after TKA. Other factors that can be associated with postoperative dissatisfaction include low social support and poverty ${ }^{18,37)}$, living alone ${ }^{28}$, and postoperative varus knee alignment ${ }^{3)}$. Mann et al. ${ }^{46)}$ observed improvements in outcome scores after revision TKA when it was performed by a different surgeon from the primary TKA that was considered as failure; therefore, they concluded that dissatisfaction with a previ- 


\section{Choi and Ra. Patient Satisfaction after TKA}

ous TKA does not predispose to continued dissatisfaction after revision.

\section{External Components of Patient Satisfaction}

External components that can be associated with patient satisfaction include anesthesia, postoperative pain management, surgical technique, implant type, and postoperative rehabilitation.

\section{1) Anesthesia and postoperative pain management}

Some studies have associated anesthesia and postoperative pain management with patient satisfaction. In general, TKA is performed under regional or general anesthesia. According to a literature review by Fischer et al. ${ }^{47)}$, regional anesthesia appears to result in greater patient satisfaction after TKA. However, in a study by Harsten et al. ${ }^{48)}$ where the results of TKA were compared among patients randomly allocated to receive either general anesthesia or spinal anesthesia during surgery, the general anesthesia group obtained more favorable results than the spinal anesthesia group in terms of early recovery, pain relief, dizziness or nausea, and early ambulation. A variety of attempts have been made for initial pain relief after TKA and ultimately for improved patient satisfaction. In the past, narcotic analgesics were prescribed for pain control after TKA; however, it is used less frequently these days due to the risk of complications ${ }^{49)}$. According to Andersen and Kehlet ${ }^{50)}$, intraoperative periarticular injections may contribute to pain relief and reduced use of narcotic analgesics. Femoral nerve blocks that are effective for postoperative pain management may also decrease the need for narcotic analgesics ${ }^{51)}$. However, consensus on the efficacy of sciatic nerve blockade still remains elusive $e^{52,53)}$.

\section{2) Surgical technique}

Minimally invasive TKA performed through a small incision accelerates recovery after surgery. Thus, it has been expected to improve patient satisfaction after TKA. However, HernandezVaquero et al. ${ }^{54)}$ reported that minimally invasive technique and the traditional surgical technique did not demonstrate significant differences in satisfaction among TKA patients. Therefore, the influence of surgical technique on patient satisfaction should be investigated in further research.

\section{3) Type of implant}

In spite of being established as an effective surgical technique, TKA has evolved continuously to better accommodate patients' desire for functional improvement. The impact of implant design on the outcome of TKA has been studied by many researchers, and some of which have demonstrated a relationship between the type of implant and postoperative satisfaction. Hamilton et al. ${ }^{55)}$ conducted a prospective, double-blind randomized control trial for comparison of Kinemax TKA and Triathlon TKA, which showed that the outcome of TKA could be influenced by the prosthesis design. Baker et al. ${ }^{56)}$ carried out comparisons of 6 different TKA implants: the NexGen implant (Zimmer, Warsaw, IN, USA) resulted in greater improvement after TKA than the other 5 implant types. Contrary to these studies, a multi-center randomized controlled trial by Wylde et al. ${ }^{57)}$ showed no significant difference in patient satisfaction between the Kinemax fixed- and mobile-bearing TKA.

\section{4) Postoperative rehabilitation}

Recently, Levine et al. $^{58)}$ reported that rehabilitation managed by a physical therapist did not result in difference in patient satisfaction and functioning compared to neuromuscular electrical stimulation performed at home without therapist's supervision. Kim et al. ${ }^{59)}$ also reported that regular passive ROM exercises did not offer additional clinical benefits to TKA patients. However, we believe that systematic rehabilitation guided by a physical therapist would be conducive to a more rapid return to normal daily activities.

\section{Conclusions}

TKA has been recognized as a successful treatment for knee arthritis that delivers relatively high satisfaction compared to the other surgical treatments from the orthopedic surgeon's perspective. However, it is not uncommon to observe discrepancies in patient-surgeon satisfaction: patients are often less satisfied the outcome than the surgeons expect, suggesting the need to develop more objective patient satisfaction measures. Among various factors that contribute to patient satisfaction, some factors can be managed by the surgeon, which should be improved through continuous research. One of the factors most strongly associated with postoperative satisfaction is patient's expectations: unmet expectations result in dissatisfaction. Therefore, it is important for surgeons to reach an agreement with patients on the possible benefits and risks of TKA through extensive discussion and explanation before surgery in order to reduce the likelihood of patient dissatisfaction. 


\section{Conflict of Interest}

No potential conflict of interest relevant to this article was reported.

\section{References}

1. Juni P, Reichenbach S, Dieppe P. Osteoarthritis: rational approach to treating the individual. Best Pract Res Clin Rheumatol. 2006;20:721-40.

2. Lau RL, Gandhi R, Mahomed S, Mahomed N. Patient satisfaction after total knee and hip arthroplasty. Clin Geriatr Med. 2012;28:349-65.

3. Matsuda S, Kawahara S, Okazaki K, Tashiro Y, Iwamoto Y. Postoperative alignment and ROM affect patient satisfaction after TKA. Clin Orthop Relat Res. 2013;471:127-33.

4. Harris IA, Harris AM, Naylor JM, Adie S, Mittal R, Dao AT. Discordance between patient and surgeon satisfaction after total joint arthroplasty. J Arthroplasty. 2013;28:722-7.

5. Sitzia J, Wood N. Patient satisfaction: a review of issues and concepts. Soc Sci Med. 1997;45:1829-43.

6. Dunbar MJ. Subjective outcomes after knee arthroplasty. Acta Orthop Scand Suppl. 2001;72:1-63.

7. Ware JE Jr, Snyder MK, Wright WR, Davies AR. Defining and measuring patient satisfaction with medical care. Eval Program Plann. 1983;6:247-63.

8. Dunbar MJ, Richardson G, Robertsson O. I can't get no satisfaction after my total knee replacement: rhymes and reasons. Bone Joint J. 2013;95(11 Suppl A):148-52.

9. Schulze A, Scharf HP. Satisfaction after total knee arthroplasty: comparison of 1990-1999 with 2000-2012. Orthopade. 2013;42:858-65.

10. Baker PN, Rushton S, Jameson SS, Reed M, Gregg P, Deehan DJ. Patient satisfaction with total knee replacement cannot be predicted from pre-operative variables alone: a cohort study from the National Joint Registry for England and Wales. Bone Joint J. 2013;95:1359-65.

11. Kim SJ, Bamne A, Song YD, Kang YG, Kim TK. Patients still wish for key improvements after total knee arthroplasty. Knee Surg Relat Res. 2015;27:24-33.

12. Scuderi GR, Bourne RB, Noble PC, Benjamin JB, Lonner JH, Scott WN. The new Knee Society Knee Scoring System. Clin Orthop Relat Res. 2012;470:3-19.

13. Stewart AL, Hays RD, Ware JE Jr. The MOS short-form general health survey: reliability and validity in a patient population. Med Care. 1988;26:724-35.
14. Bellamy N, Buchanan WW, Goldsmith CH, Campbell J, Stitt LW. Validation study of WOMAC: a health status instrument for measuring clinically important patient relevant outcomes to antirheumatic drug therapy in patients with osteoarthritis of the hip or knee. J Rheumatol. 1988;15:1833-40.

15. Roos EM, Roos HP, Lohmander LS, Ekdahl C, Beynnon BD. Knee Injury and Osteoarthritis Outcome Score (KOOS): development of a self-administered outcome measure. J Orthop Sports Phys Ther. 1998;28:88-96.

16. Dawson J, Fitzpatrick R, Murray D, Carr A. Questionnaire on the perceptions of patients about total knee replacement. J Bone Joint Surg Br. 1998;80:63-9.

17. van Hove RP, Brohet RM, van Royen BJ, Nolte PA. High correlation of the Oxford knee score with postoperative pain, but not with performance-based functioning. Knee Surg Sports Traumatol Arthrosc. 2015 Mar 29 [Epub]. http://dx. doi.org/10.1007/s00167-015-3585-9.

18. Judge A, Arden NK, Cooper C, Kassim Javaid M, Carr AJ, Field RE, Dieppe PA. Predictors of outcomes of total knee replacement surgery. Rheumatology (Oxford). 2012;51:1804-13.

19. Scott CE, Bugler KE, Clement ND, MacDonald D, Howie CR, Biant LC. Patient expectations of arthroplasty of the hip and knee. J Bone Joint Surg Br. 2012;94:974-81.

20. Ghomrawi HM, Franco Ferrando N, Mandl LA, Do H, Noor N, Gonzalez Della Valle A. How often are patient and surgeon recovery expectations for total joint arthroplasty aligned? Results of a pilot study. HSS J. 2011;7:229-34.

21. Parvizi J, Nunley RM, Berend KR, Lombardi AV Jr, Ruh EL, Clohisy JC, Hamilton WG, Della Valle CJ, Barrack RL. High level of residual symptoms in young patients after total knee arthroplasty. Clin Orthop Relat Res. 2014;472:133-7.

22. Noble PC, Conditt MA, Cook KF, Mathis KB. The John Insall Award: patient expectations affect satisfaction with total knee arthroplasty. Clin Orthop Relat Res. 2006;452:35-43.

23. Williams DP, Price AJ, Beard DJ, Hadfield SG, Arden NK, Murray DW, Field RE. The effects of age on patient-reported outcome measures in total knee replacements. Bone Joint J. 2013;95:38-44.

24. Von Keudell A, Sodha S, Collins J, Minas T, Fitz W, Gomoll AH. Patient satisfaction after primary total and unicompartmental knee arthroplasty: an age-dependent analysis. Knee. 2014;21:180-4.

25. Bonnin MP, Basiglini L, Archbold HA. What are the factors of residual pain after uncomplicated TKA? Knee Surg Sports Traumatol Arthrosc. 2011;19:1411-7.

26. Fisher DA, Dierckman B, Watts MR, Davis K. Looks good 
but feels bad: factors that contribute to poor results after total knee arthroplasty. J Arthroplasty. 2007;22(6 Suppl 2):39-42.

27. Gong L, Dong JY. Patient's personality predicts recovery after total knee arthroplasty: a retrospective study. J Orthop Sci. 2014;19:263-9.

28. Bourne RB, Chesworth BM, Davis AM, Mahomed NN, Charron KD. Patient satisfaction after total knee arthroplasty: who is satisfied and who is not? Clin Orthop Relat Res. 2010;468:57-63.

29. Scott CE, Howie CR, MacDonald D, Biant LC. Predicting dissatisfaction following total knee replacement: a prospective study of 1217 patients. J Bone Joint Surg Br. 2010;92: 1253-8.

30. Noble PC, Fuller-Lafreniere S, Meftah M, Dwyer MK. Challenges in outcome measurement: discrepancies between patient and provider definitions of success. Clin Orthop Relat Res. 2013;471:3437-45.

31. Haanstra TM, van den Berg T, Ostelo RW, Poolman RW, Jansma EP, Cuijpers P, de Vet HC. Systematic review: do patient expectations influence treatment outcomes in total knee and total hip arthroplasty? Health Qual Life Outcomes. 2012;10:152.

32. Culliton SE, Bryant DM, Overend TJ, MacDonald SJ, Chesworth BM. The relationship between expectations and satisfaction in patients undergoing primary total knee arthroplasty. J Arthroplasty. 2012;27:490-2.

33. Pivec R, Issa K, Given K, Harwin SF, Greene KA, Hitt KD, Shi S, Mont MA. A prospective, longitudinal study of patient satisfaction following total knee arthroplasty using the Short-Form 36 (SF-36) survey stratified by various demographic and comorbid factors. J Arthroplasty. 2015;30:374-8.

34. Singh JA, Lewallen DG. Medical and psychological comorbidity predicts poor pain outcomes after total knee arthroplasty. Rheumatology (Oxford). 2013;52:916-23.

35. Clement ND, Burnett R. Patient satisfaction after total knee arthroplasty is affected by their general physical well-being. Knee Surg Sports Traumatol Arthrosc. 2013;21:2638-46.

36. Vissers MM, Bussmann JB, Verhaar JA, Busschbach JJ, Bierma-Zeinstra SM, Reijman M. Psychological factors affecting the outcome of total hip and knee arthroplasty: a systematic review. Semin Arthritis Rheum. 2012;41:576-88.

37. Wylde V, Dieppe P, Hewlett S, Learmonth ID. Total knee replacement: is it really an effective procedure for all? Knee. 2007;14:417-23.

38. Duivenvoorden T, Vissers MM, Verhaar JA, Busschbach JJ, Gosens T, Bloem RM, Bierma-Zeinstra SM, Reijman M.
Anxiety and depressive symptoms before and after total hip and knee arthroplasty: a prospective multicentre study. Osteoarthritis Cartilage. 2013;21:1834-40.

39. Perez-Prieto D, Gil-Gonzalez S, Pelfort X, Leal-Blanquet J, Puig-Verdie L, Hinarejos P. Influence of depression on total knee arthroplasty outcomes. J Arthroplasty. 2014;29:44-7.

40. Robertsson O, Dunbar M, Pehrsson T, Knutson K, Lidgren L. Patient satisfaction after knee arthroplasty: a report on 27,372 knees operated on between 1981 and 1995 in Sweden. Acta Orthop Scand. 2000;71:262-7.

41. Bullens PH, van Loon CJ, de Waal Malefijt MC, Laan RF, Veth RP. Patient satisfaction after total knee arthroplasty: a comparison between subjective and objective outcome assessments. J Arthroplasty. 2001;16:740-7.

42. Maratt JD, Lee YY, Lyman S, Westrich GH. Predictors of satisfaction following total knee arthroplasty. J Arthroplasty. 2015;30:1142-5.

43. Kim TK, Chang CB, Kang YG, Kim SJ, Seong SC. Causes and predictors of patient's dissatisfaction after uncomplicated total knee arthroplasty. J Arthroplasty. 2009;24:263-71.

44. Schnurr C, Jarrous M, Gudden I, Eysel P, Konig DP. Preoperative arthritis severity as a predictor for total knee arthroplasty patients' satisfaction. Int Orthop. 2013;37:1257-61.

45. Polkowski GG 2nd, Ruh EL, Barrack TN, Nunley RM, Barrack RL. Is pain and dissatisfaction after TKA related to early-grade preoperative osteoarthritis? Clin Orthop Relat Res. 2013;471:162-8.

46. Mann MA, Smith K, Banack HR, Tanzer M. Changing surgeons improves outcome of subsequent primary total joint arthroplasty in previously dissatisfied patients. J Arthroplasty. 2013;28:736-9.

47. Fischer HB, Simanski CJ, Sharp C, Bonnet F, Camu F, Neugebauer EA, Rawal N, Joshi GP, Schug SA, Kehlet H; PROSPECT Working Group. A procedure-specific systematic review and consensus recommendations for postoperative analgesia following total knee arthroplasty. Anaesthesia. 2008;63:1105-23.

48. Harsten A, Kehlet H, Toksvig-Larsen S. Recovery after total intravenous general anaesthesia or spinal anaesthesia for total knee arthroplasty: a randomized trial. Br J Anaesth. 2013; 111:391-9.

49. Horlocker TT, Kopp SL, Pagnano MW, Hebl JR. Analgesia for total hip and knee arthroplasty: a multimodal pathway featuring peripheral nerve block. J Am Acad Orthop Surg. 2006;14:126-35.

50. Andersen LO, Kehlet H. Analgesic efficacy of local infiltra- 
tion analgesia in hip and knee arthroplasty: a systematic review. Br J Anaesth. 2014;113:360-74.

51. C Wyatt M, Wright T, Locker J, Stout K, Chapple C, Theis JC. Femoral nerve infusion after primary total knee arthroplasty: a prospective, double-blind, randomised and placebo-controlled trial. Bone Joint Res. 2015;4:11-6.

52. Allen HW, Liu SS, Ware PD, Nairn CS, Owens BD. Peripheral nerve blocks improve analgesia after total knee replacement surgery. Anesth Analg. 1998;87:93-7.

53. Morin AM, Kratz CD, Eberhart LH, Dinges G, Heider E, Schwarz N, Eisenhardt G, Geldner G, Wulf H. Postoperative analgesia and functional recovery after total-knee replacement: comparison of a continuous posterior lumbar plexus (psoas compartment) block, a continuous femoral nerve block, and the combination of a continuous femoral and sciatic nerve block. Reg Anesth Pain Med. 2005;30:434-45.

54. Hernandez-Vaquero D, Noriega-Fernandez A, SuarezVazquez A. Total knee arthroplasties performed with a miniincision or a standard incision: similar results at six months follow-up. BMC Musculoskelet Disord. 2010;11:27.

55. Hamilton DF, Burnett R, Patton JT, Howie CR, Moran M,
Simpson AH, Gaston P. Implant design influences patient outcome after total knee arthroplasty: a prospective double-blind randomised controlled trial. Bone Joint J. 2015;97:64-70.

56. Baker PN, Deehan DJ, Lees D, Jameson S, Avery PJ, Gregg PJ, Reed MR. The effect of surgical factors on early patientreported outcome measures (PROMS) following total knee replacement. J Bone Joint Surg Br. 2012;94:1058-66.

57. Wylde V, Learmonth I, Potter A, Bettinson K, Lingard E. Patient-reported outcomes after fixed- versus mobilebearing total knee replacement: a multi-centre randomised controlled trial using the Kinemax total knee replacement. J Bone Joint Surg Br. 2008;90:1172-9.

58. Levine M, McElroy K, Stakich V, Cicco J. Comparing conventional physical therapy rehabilitation with neuromuscular electrical stimulation after TKA. Orthopedics. 2013;36: e319-24.

59. Kim TK, Park KK, Yoon SW, Kim SJ, Chang CB, Seong SC. Clinical value of regular passive ROM exercise by a physical therapist after total knee arthroplasty. Knee Surg Sports Traumatol Arthrosc. 2009;17:1152-8. 


\section{Choi and Ra. Patient Satisfaction after TKA}

Appendix 1. Knee Society Score (KSS)

\begin{tabular}{|c|c|c|c|}
\hline \multicolumn{3}{|c|}{ Part 1. Knee score (point) } & Part 2. Function score (point) \\
\hline \multicolumn{3}{|l|}{ Pain } & Walking \\
\hline \multicolumn{3}{|l|}{ None (50) } & Unlimited (50) \\
\hline \multicolumn{3}{|c|}{ Mild/occasional (45) } & $>10$ blocks $(40)$ \\
\hline \multicolumn{3}{|c|}{ Mild (stairs only) (40) } & 5-10 blocks (30) \\
\hline \multicolumn{3}{|c|}{ Mild (walking and stairs) (30) } & $<5$ blocks $(20)$ \\
\hline \multicolumn{3}{|c|}{ Moderate (occasional) (20) } & Housebound (10) \\
\hline \multicolumn{3}{|c|}{ Moderate (continual) (10) } & Unable $(0)$ \\
\hline \multicolumn{3}{|l|}{ Severe $(0)$} & Stairs \\
\hline \multicolumn{3}{|c|}{ Total range of flexion $\left({ }^{\circ}\right)$} & Normal up and down (50) \\
\hline $0-5(1)$ & $46-50(10)$ & $91-95(19)$ & Normal up down with rail (40) \\
\hline $6-10(2)$ & $51-55(11)$ & $96-100(20)$ & Up and down with rail (30) \\
\hline $11-15(3)$ & $56-60(12)$ & $101-105(21)$ & Up with rail, down unable (15) \\
\hline $16-20(4)$ & $61-65(13)$ & $106-110(22)$ & Unable (0) \\
\hline $21-25(5)$ & $66-70(14)$ & $111-115(23)$ & Walking aids used \\
\hline $26-30(6)$ & $71-75(15)$ & $116-120(24)$ & None used $(0)$ \\
\hline $31-35(7)$ & $76-80(16)$ & $121-125(25)$ & Use of cane/walking stick deduct $(-5)$ \\
\hline $36-40(8)$ & $81-85(17)$ & & Two canes/sticks $(-10)$ \\
\hline $41-45(9)$ & $86-90(18)$ & & Crutches or frame $(-20)$ \\
\hline \multicolumn{3}{|c|}{ Flexion contracture (if present) $\left({ }^{\circ}\right)$} & Final knee score is: \\
\hline \multicolumn{3}{|l|}{$5-10(-2)$} & Grading for the KSS \\
\hline \multicolumn{3}{|l|}{$10-15(-5)$} & Excellent (80-100) \\
\hline \multicolumn{3}{|l|}{$16-20(-10)$} & Good (70-79) \\
\hline \multicolumn{2}{|l|}{$>20(-15)$} & & Fair (60-69) \\
\hline \multicolumn{2}{|c|}{ Alignment (varus \& valgus) $\left(^{\circ}\right)$} & & Poor $(<60)$ \\
\hline $0(-15)$ & \multicolumn{3}{|l|}{$11(-3)$} \\
\hline $1(-12)$ & \multicolumn{3}{|l|}{$12(-6)$} \\
\hline $2(-9)$ & \multicolumn{3}{|l|}{$13(-9)$} \\
\hline $3(-6)$ & \multicolumn{3}{|l|}{$14(-12)$} \\
\hline $4(-3)$ & \multicolumn{3}{|l|}{$15(-15)$} \\
\hline $5-10(0)$ & \multicolumn{3}{|l|}{ Over $15(-20)$} \\
\hline \multicolumn{4}{|c|}{ Stability (maximum movement in any position) } \\
\hline \multicolumn{4}{|c|}{ Anteroposterior (mm) } \\
\hline \multicolumn{4}{|l|}{$<5(10)$} \\
\hline \multicolumn{4}{|l|}{$5-10(5)$} \\
\hline \multicolumn{4}{|l|}{$10+(0)$} \\
\hline Mediolater & & & \\
\hline$<5(15)$ & & & \\
\hline $6-9(10)$ & & & \\
\hline $10-14(5)$ & & & \\
\hline $15(0)$ & & & \\
\hline
\end{tabular}


Appendix 2. The New Knee Society Score

\begin{tabular}{l}
\hline Objective knee score ( 7 items, 100 points) (point) \\
\hline Anteroposterior alignment \\
Stability (25) \\
Medial/lateral (15) \\
Anterior/posterior (10) \\
Range of motion (25) \\
Symptoms (25) \\
Deductions \\
Malalignment $(-10)$ \\
Flexion contracture $(-2,-5,-10,-15)$ \\
Extensor lag $(-5,-10,-15)$
\end{tabular}

Satisfaction score ( 5 items, 40 points)

Pain level while sitting

Pain level while lying in bed

Knee function while getting out of bed

Knee function while performing light household duties

Knee function while performing leisure recreational activities

\begin{tabular}{l} 
Expectation score ( 3 items, 15 points) \\
\hline Pain relief \\
Ability to carry out activities of daily living \\
Ability to perform leisure, recreational, or sport activities
\end{tabular}

Functional activity score (19 items, 100 points) (point)

Walking and standing (5 items, 30 points)

1. Can you walk without any aids (such as a cane, crutches or wheelchair)? $\square$ Yes $\square$ No

2. If no, which of the following aid(s) do you use?

$\square$ Wheelchair $(-10)$

$\square$ One crutch $(-4)$

$\square$ Walker (-8)

$\square$ One cane $(-4)$

$\square$ Crutches $(-8)$

$\square$ Knee sleeve/brace $(-2)$

$\square$ Two canes (-6)

3. Do you use these aid(s) because of your knees? $\quad \square$ Yes $\square$ No

4. For how long can you stand (with or without aid) before sitting due to knee discomfort?

$\begin{array}{ll}\square \text { Cannot stand (0) } & \square 0-5 \min (3) \\ \square 6-15 \min (6) & \square 16-30 \min (9) \\ \square 31-60 \min (12) & \square \text { More than an hour (15) }\end{array}$

5. For how long can you walk (with or without aid) before stopping due to knee discomfort?
$\square$ Cannot walk (0)
$\square 0-5 \min (3)$
$\square$ 6-15 $\min (6)$
$\square$ 16-30 $\min (9)$
$\square 31-60 \min (12)$
$\square$ More than an hour (15)

Appendix 2. Continued

Standard activities (6 items, 30 points)

1. Walking on an uneven surface (5 points)

2. Turning or pivoting on your leg (5 points)

3. Climbing up or down a flight of stairs (5 points)

4. Getting up from a low couch or a chair without arms (5 points)

5. Getting into or out of a car (5 points)

6. Moving laterally (stepping to the side) (5 points)

Advanced activities (5 items, 25 points)

1. Climbing a ladder or step stool (5 points)

2. Carrying a shopping bag for a block (5 points)

3. Squatting (5 points)

4. Kneeling (5 points)

5. Running (5 points)

Discretionary activities ( 3 items, 15 points)

Check 3 of the activities below that you consider most important to you.

Recreational actibities

Swimming

Golfing (18 holes)

Road cycling (>30 mins)

Gardening

Bowling

Racquet sports (tennis, racquetball, etc.)

Distance walking

Dancing/ballet

Stretching exercises (stretching out your muscles

Workout and gym activities

Weight lifting

Leg Extensions

Stair climber

Stationary biking/spinning

Leg press

Jogging

Elliptical trainer

Aerobic exercises

Please copy all 3 checked activities into the empty boxes below.

How much does your knee bother you during each of these activities? Activity $\begin{gathered}\text { No } \\ \text { bother }\end{gathered}$ Slight Moderate Severe $\begin{gathered}\text { Vere } \\ \text { severe }\end{gathered} \begin{gathered}\text { Cannot } \\ \text { (because } \\ \text { of knee) }\end{gathered}$

Write the 3 activies from list above

1.

2.

3. 
Appendix 3. Short Form Health Survey (SF-36)

This survey asks for your views about your health. This information will help you keep track of how you feel and how well you are able to do your usual activities.

Answer every question by selecting the answer as indicated. If you are unsure about how to answer a question, please give the best answer you can.

1. In general, would you say your health is

$\begin{array}{ll}\square \text { Excellent } & \square \text { Very good } \quad \square \text { Good } \\ \square \text { Fair } & \square \text { Poor }\end{array}$

2. Compared to one year ago, how would you rate your health in general now?

$\square$ Much better now than 1 year ago

$\square$ Somewhat better now than 1 year ago

$\square$ About the same as 1 year ago

$\square$ Somewhat worse now than 1 year ago

$\square$ Much worse now than 1 year ago

3. The following questions are about activities you might do during a typical day. Does your health now limit you in these activities? If so, how much?

$$
\begin{array}{ccc}
\text { Yes, limited } & \text { Yes, limited } & \text { No, not } \\
\text { a lot } & \text { a little } & \text { limited at all }
\end{array}
$$

a. Vigorous activities, such as running, lifting heavy objects, participating in strenuous sports

b. Moderate activities, such as moving a table, pushing a vacuum cleaner, bowling, or playing golf

c. Lifting or carrying groceries

d. Climbing several flights of stairs

e. Climbing one flight of stairs

f. Bending, kneeling, or stooping

g. Walking more than a mile

h. Walking several blocks

i. Walking one block

j. Bathing or dressing yourself

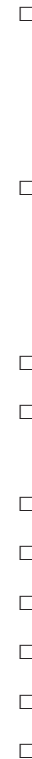

4. During the past 4 weeks, have you had any of the following problems with your work or other regular daily activities as a result of your physical health?

a. Cut down on the amount of time you Yes

No spent on work or other activities

b. Accomplished less than you would like

c. Were limited in the kind of work or other activities

d. Had difficulty performing the work or other activities (for example, it took extra effort)

\section{Appendix 3. Continued}

5. During the past 4 weeks, have you had any of the following problems with your work or other regular daily activities as a result of any emotional problems (such as feeling depressed or anxious)?

Yes No

a. Cut down on the amount of time you spent on $\quad \square \quad \square$

work or other activities

b. Accomplished less than you would like $\quad \square \quad \square$

c. Did work or other activities less carefully than usual $\quad \square \quad \square$

6. During the past 4 weeks, to what extent has your physical health or emotional problems interfered with your normal social activities with family, friends, neighbors, or groups?

$\square$ Not at all

$\square$ Slightly

$\square$ Moderately

$\square$ Quite a bit

$\square$ Extremely

7. How much bodily pain have you had during the past 4 weeks?

$\square$ None

$\square$ Very mild

$\square$ Mild

$\square$ Moderate

$\square$ Severe

$\square$ Very severe

8. During the past 4 weeks, how much did pain interfere with your normal work (including both work outside the home and housework)

$\square$ Not at all

$\square$ A little bit

$\square$ Moderately

$\square$ Quite a bit

$\square$ Extremely

9. These questions are about how you feel and how things have been with you during the past 4 weeks. For each question, please give the one answer that comes closest to the way you have been feeling. How much of the time during the past 4 weeks.

\begin{tabular}{|c|c|c|c|c|c|}
\hline a. Did you feel full of pep? & $\square$ & $\square$ & $\square$ & $\square$ & $\square$ \\
\hline $\begin{array}{l}\text { b. Have you been a very } \\
\text { nervous person? }\end{array}$ & $\square$ & $\square$ & $\square$ & $\square$ & $\square$ \\
\hline $\begin{array}{l}\text { c. Have you felt so down } \\
\text { in the dumps }\end{array}$ & $\square$ & $\square$ & $\square$ & $\square$ & $\square$ \\
\hline $\begin{array}{l}\text { d. Have you felt calm and } \\
\text { peaceful? }\end{array}$ & $\square$ & $\square$ & $\square$ & $\square$ & $\square$ \\
\hline $\begin{array}{l}\text { e. Did you have a lot of } \\
\text { energy? }\end{array}$ & $\square$ & $\square$ & $\square$ & $\square$ & $\square$ \\
\hline $\begin{array}{l}\text { f. Have you felt down- } \\
\text { hearted and blue? }\end{array}$ & $\square$ & $\square$ & $\square$ & $\square$ & $\square$ \\
\hline g. Did you feel worn out? & $\square$ & $\square$ & $\square$ & $\square$ & $\square$ \\
\hline $\begin{array}{l}\text { h. Have you been a happy } \\
\text { person? }\end{array}$ & $\square$ & $\square$ & $\square$ & $\square$ & $\square$ \\
\hline i. Did you feel tired? & $\square$ & $\square$ & $\square$ & $\square$ & $\square$ \\
\hline
\end{tabular}

All Most A good bit Some A little None 
Appendix 3. Continued

10. During the past 4 weeks, how much of the time has your physical health or emotional problems interfered with your social activities (like visiting friends, relatives, etc.)?

$\square$ All of the time

$\square$ Most of the time

$\square$ Some of the time

$\square$ A little of the time

$\square$ None of the time

11. How 'true' or 'false' is each of the following statements for you?

Definitely Mostly Don't Mostly Definitely true true know false false

$\begin{array}{lccccc}\text { a. I seem to get sick a little } & \square & \square & \square & \square & \square \\ \text { easier than other people } & & & & \\ \text { b. I am as healthy as any- } & \square & \square & \square & \square & \square \\ \text { body I know } & & & & & \\ \text { c. I expect my health to } & \square & \square & \square & \square & \square \\ \text { get worse } & & & & & \\ \text { d. My health is excellent } & \square & \square & \square & \square & \square\end{array}$




\section{Choi and Ra. Patient Satisfaction after TKA}

Appendix 4. Short Form Health Survey (SF-12)

This survey asks for your views about your health. This information will help you keep track of how you feel and how well you are able to do your usual activities. Answer every question by selecting the answer as indicated. If you are unsure about how to answer a question, please give the best answer you can.

1. In general, would you say your health is:

$\square$ Excellent $\quad \square$ Very good $\quad \square$ Good $\quad \square$ Fair $\quad \square$ Poor

2. The following questions are about activities you might do during a typical day. Does your health now limit you in these activities? If so, how much?

$\begin{array}{ccc}\text { Yes, } & \text { Yes, } & \text { No, } \\ \text { limited a lot } & \text { limited a little } & \text { not limited at all } \\ \square & \square & \square \\ \square & \square & \square\end{array}$
a. Moderate activities, such as moving a table, pushing a vacuum cleaner, bowling, or playing golf
b. Climbing several flights of stairs

3. During the past 4 weeks, have you had any of the following problems with your work or other regular daily activities as a result of your physical health?
a. Accomplished less than you would like
Yes
No
b. Were limited in the kind of work or other activities

4. During the past 4 weeks, have you had any of the following problems with your work or other regular daily activities as a result of any emotional problems (such as feeling depressed or anxious)?
a. Accomplished less than you would like
b. Did work or other activities less carefully than usual
$\square \quad \square$

Yes

No

5. During the past 4 weeks, how much did pain interfere with your normal work (including both work outside the home and housework)?
$\square$ Not at all
$\square$ A little bit
$\square$ Moderately
$\square$ Quite a bit
$\square$ Extremely

6. These questions are about how you feel and how things have been with you during the past 4 weeks. For each question, please give the one answer that comes closest to the way you have been feeling.

How much of the time during the past 4 weeks..

a. Have you felt calm and peaceful?

b. Did you have a lot of energy?

c. Did you have a lot of energy?

$\begin{array}{cccccc}\text { All } & \text { Most } & \text { A good bit } & \text { Some } & \text { A little } & \text { None } \\ \square & \square & \square & \square & \square & \square \\ \square & \square & \square & \square & \square & \square \\ \square & \square & \square & \square & \square & \square\end{array}$

7. During the past 4 weeks, how much of the time has your physical health or emotional problems interfered with your social activities (like visiting friends, relatives, etc.)?

$\square$ All $\quad \square$ Most $\square$ Some $\square$ A little $\square$ None


Appendix 5. The Western Ontario and McMaster Universities (WOMAC) Index of Osteoarthritis

Overview:

The WOMAC Index is used to assess patients with osteoarthritis of the hip or knee using 24 parameters. It can be used to monitor the course of the disease or to determine the effectiveness of anti-rheumatic medications.

While the index was being developed performance of social functions and the status of emotional function were also included. These were not included in the final instrument.

\begin{tabular}{|c|c|}
\hline Pain & Social function \\
\hline Walking (1) & Leisure activities (1) \\
\hline Stair climbing (2) & Community events (2) \\
\hline Nocturnal (3) & Church attendance (3) \\
\hline Rest (4) & With spouse (4) \\
\hline Weight bearing (5) & With family (5) \\
\hline Stiffness & With friends (6) \\
\hline Morning stiffness (1) & With others (7) \\
\hline Stiffness occurring later in the day (2) & Emotional function \\
\hline Rising from sitting (3) & Anxiety (1) \\
\hline Standing (4) & Irritability (2) \\
\hline Bending to floor (5) & Frustration (3) \\
\hline Walking on flat (6) & Depression (4) \\
\hline Getting in or out of car (7) & Relaxation (5) \\
\hline Going shopping (8) & Insomnia (6) \\
\hline Putting on socks (9) & Boredom (7) \\
\hline Rising from bed (10) & Loneliness (8) \\
\hline Taking off socks (11) & Stress (9) \\
\hline Lying in bed (12) & Well-being (10) \\
\hline Getting in or out of bath(13) & Scoring and interpretation \\
\hline Sitting (14) & Response \\
\hline Getting on or off toilet (15) & None $(0)$ \\
\hline Heavy domestic duties (16) & Slight (1) \\
\hline \multirow[t]{5}{*}{ Light domestic duties (17) } & Moderate (2) \\
\hline & Severe (3) \\
\hline & Extreme (4) \\
\hline & $\begin{array}{l}\text { Score }=\text { sum (points for rele- } \\
\text { vant items) }\end{array}$ \\
\hline & $\begin{array}{l}\text { Average score }=(\text { total score }) / \\
\quad(\text { no. of items) }\end{array}$ \\
\hline
\end{tabular}

Appendix 6. Knee Injury and Osteoarthritis Outcome Score (KOOS)

Symptoms

These questions should be answered thinking of your knee symptoms during the last week.

S1. Do you have swelling in your knee?

$\square$ Never $\square$ Rarely $\square$ Sometimes $\square$ Often $\square$ Always

S2. Do you feel grinding, hear clicking or any other type of noise when your knee moves?

$\square$ Never $\square$ Rarely $\square$ Sometimes $\square$ Often $\square$ Always

S3. Does your knee catch or hang up when moving?

$\square$ Never $\square$ Rarely $\square$ Sometimes $\square$ Often $\square$ Always

S4. Can you straighten your knee fully?

$\square$ Never $\square$ Rarely $\square$ Sometimes $\square$ Often $\square$ Always

S5. Can you bend your knee fully?

$\square$ Never $\square$ Rarely $\square$ Sometimes $\square$ Often $\square$ Always

Stiffness

The following questions concern the amount of joint stiffness you have experienced during the last week in your knee. Stiffness is a sensation of restriction or slowness in the ease with which you move your knee joint.

S6. How severe is your knee joint stiffness after first wakening in the morning?

$\square$ None $\square$ Mild $\square$ Moderate $\square$ Severe $\square$ Extreme

S7. How severe is your knee stiffness after sitting, lying or resting later in the day?

$\square$ None $\square$ Mild $\square$ Moderate $\square$ Severe $\square$ Extreme

Subtotal:

Pain

P1. How often do you experience knee pain?

$\square$ Never $\square$ Monthly $\square$ Weekly $\square$ Daily $\square$ Always

What amount of knee pain have you experienced the last week during the following activities?

P2. Twisting/pivoting on your knee

$\square$ None $\square$ Mild $\square$ Moderate $\square$ Severe $\square$ Extreme

P3. Straightening knee fully

$\square$ None $\square$ Mild $\square$ Moderate $\square$ Severe $\square$ Extreme

P4. Bending knee fully

$\square$ None $\square$ Mild $\square$ Moderate $\square$ Severe $\square$ Extreme

P5. Walking on flat surface

$\square$ None $\square$ Mild $\square$ Moderate $\square$ Severe $\square$ Extreme

P6. Going up or down stairs

$\square$ None $\square$ Mild $\square$ Moderate $\square$ Severe $\square$ Extreme

P7. At night while in bed

$\square$ None $\square$ Mild $\square$ Moderate $\square$ Severe $\square$ Extreme

P8. Sitting or lying

$\square$ None $\square$ Mild $\square$ Moderate $\square$ Severe $\square$ Extreme

P9. Standing upright

$\square$ None $\square$ Mild $\square$ Moderate $\square$ Severe $\square$ Extreme Subtotal: 
Appendix 6. Continued

Function, daily living

The following questions concern your physical function. By this we mean your ability to move around and to look after yourself. For each of the following activities please indicate the degree of difficulty you have experienced in the last week due to your knee.

\section{A1. Descending stairs \\ $\square$ None $\square$ Mild $\square$ Moderate $\square$ Severe $\square$ Extreme \\ A2. Ascending stairs \\ $\square$ None $\square$ Mild $\square$ Moderate $\square$ Severe $\square$ Extreme}

For each of the following activities please indicate the degree of difficulty you have experienced in the last week due to your knee.

A3. Rising from sitting

$\square$ None $\square$ Mild $\square$ Moderate $\square$ Severe $\square$ Extreme

A4. Standing

$\square$ None $\square$ Mild $\square$ Moderate $\square$ Severe $\square$ Extreme

A5. Bending to floor/pick up an object

$\square$ None $\square$ Mild $\square$ Moderate $\square$ Severe $\square$ Extreme

A6. Walking on flat surface

$\square$ None $\square$ Mild $\square$ Moderate $\square$ Severe $\square$ Extreme

A7. Getting in/out of car

$\square$ None $\square$ Mild $\square$ Moderate $\square$ Severe $\square$ Extreme

A8. Going shopping

$\square$ None $\square$ Mild $\square$ Moderate $\square$ Severe $\square$ Extreme

A9. Putting on socks/stockings

$\square$ None $\square$ Mild $\square$ Moderate $\square$ Severe $\square$ Extreme

A10. Rising from bed

$\square$ None $\square$ Mild $\square$ Moderate $\square$ Severe $\square$ Extreme

A11. Taking off socks/stockings

$\square$ None $\square$ Mild $\square$ Moderate $\square$ Severe $\square$ Extreme

A12. Lying in bed (turning over, maintaining knee position)

$\square$ None $\square$ Mild $\square$ Moderate $\square$ Severe $\square$ Extreme

A13. Getting in/out of bath

$\square$ None $\square$ Mild $\square$ Moderate $\square$ Severe $\square$ Extreme

A14. Sitting

$\square$ None $\square$ Mild $\square$ Moderate $\square$ Severe $\square$ Extreme

A15. Getting on/off toilet

$\square$ None $\square$ Mild $\square$ Moderate $\square$ Severe $\square$ Extreme

For each of the following activities please indicate the degree of difficulty you have experienced in the last week due to your knee

A16. Heavy domestic duties (moving heavy boxes, scrubbing floors, etc.)

$\square$ Never $\square$ Rarely $\square$ Sometimes $\square$ Often $\square$ Always

A17. Light domestic duties (cooking, dusting, etc.)

$\square$ Never $\square$ Rarely $\square$ Sometimes $\square$ Often $\square$ Always

Subtotal:
Appendix 6. Continued

Function, sports and recreational activities

The following questions concern your physical function when being active on a higher level. The questions should be answered thinking of what degree of difficulty you have experienced during the last week due to your knee.

SP1. Squatting

$\square$ None $\square$ Mild $\square$ Moderate $\square$ Severe $\square$ Extreme

SP2. Running

$\square$ None $\square$ Mild $\square$ Moderate $\square$ Severe $\square$ Extreme

SP3. Jumping

$\square$ None $\square$ Mild $\square$ Moderate $\square$ Severe $\square$ Extreme

SP4. Twisting/pivoting on your injured knee

$\square$ None $\square$ Mild $\square$ Moderate $\square$ Severe $\square$ Extreme

SP5. Kneeling

$\square$ None $\square$ Mild $\square$ Moderate $\square$ Severe $\square$ Extreme

Subtotal:

Quality of Life

Q1. How often are you aware of your knee problem?

$\square$ Never $\square$ Monthly $\square$ Weekly $\square$ Daily $\square$ Constantly

Q2. Have you modified your life style to avoid potentially damaging activities to your knee?

$\square$ Not at all $\square$ Mildly $\square$ Moderately $\square$ Severely $\square$ Totally

Q3. How much are you troubled with lack of confidence in your knee? $\square$ Not at all $\square$ Mildly $\square$ Moderately $\square$ Severely $\square$ Extremely

Q4. In general, how much difficulty do you have with your knee?

$\square$ None $\square$ Mild $\square$ Moderate $\square$ Severe $\square$ Extreme

Subtotal:

\section{KOOS is:}

Standardized answer options are given (5 Likert boxes) and each question is assigned a score from 0 to 4 . A normalized score (100 indicating no symptoms and 0 indicating extreme symptoms) is calculated for each subscale (scoring instructions are available in a separate document: KOOS scoring). 
Appendix 7. Oxford Knee Score (OKS)

Please answer the following 12 multiple choice questions (during the past 4 weeks).

1. How would you describe the pain you usually have in your knee?

$\square$ None
$\square$ Very mild
$\square$ Mild
$\square$ Moderate
$\square$ Severe

2. Have you had any trouble washing and drying yourself (all over) because of your knee?

$\square$ No trouble at all

$\square$ Very little trouble

$\square$ Moderate trouble

$\square$ Extreme difficulty

$\square$ Impossible to do

3. Have you had any trouble getting in and out of the car or using public transport because of your knee? (with or without a stick)

$\square$ No trouble at all

$\square$ Very little trouble

$\square$ Moderate trouble

$\square$ Extreme difficulty

$\square$ Impossible to do

4. For how long are you able to walk before the pain in your knee becomes s eve re? (with or without a stick)

$\square$ No pain $>60$ min

$\square$ 16-60 min

$\square$ 5-15 min

$\square$ Around the house only

$\square$ Not at all-severe on walking

5. After a meal (sat at a table), how painful has it been for you to stand up from a chair because of your knee?

$\square$ Not at all painful

$\square$ Slightly painful

$\square$ Moderately pain

$\square$ Very painful

$\square$ Unbearable

6. Have you been limping when walking, because of your knee?

$\square$ Rarely/never

$\square$ Sometimes or just at first

$\square$ Often, not just at first

$\square$ Most of the time

$\square$ All of the time

7. Could you kneel down and get up again afterwards?

$\square$ Yes, easily

$\square$ With little difficulty

$\square$ With moderate difficulty

$\square$ With extreme difficulty

$\square$ No, impossible
Appendix 7. Continued

8 . Are you troubled by pain in your knee at night in bed?

$\square$ Not at all

$\square$ Only one or two nights

$\square$ Some nights

$\square$ Most nights

$\square$ Every night

9. How much has pain from your knee interfered with your usual work? (including housework)

$\square$ Not at all

$\square$ A little bit

$\square$ Moderately

$\square$ Greatly

$\square$ Totally

10. Have you felt that your knee might suddenly 'give way' or let you down?

$\square$ Rarely/never

$\square$ Sometimes or just at first

$\square$ Often, not at first

$\square$ Most of the time

$\square$ All the time

11. Could you do household shopping on your own?

$\square$ Yes, easily

$\square$ With little difficulty

$\square$ With moderate difficulty

$\square$ With extreme difficulty

$\square$ No, impossible

12. Could you walk down a flight of stairs?

$\square$ Yes, easily

$\square$ With little difficulty

$\square$ With moderate difficulty

$\square$ With extreme difficulty

$\square$ No, impossible

The OKS is:

Grading for the OKS

0-19 May indicate severe knee arthritis. It is highly likely that you may well require some form of surgical intervention, contact your family physician for a consult with an Orthopaedic surgeon.

20-29 May indicate moderate to severe knee arthritis. See your family physician for an assessment and X-ray. Consider a consult with an Orthopaedic surgeon.

30-39 May indicate mild to moderate knee arthritis. Consider seeing your family physician for an assessment and possible X-ray. You may benefit from non-surgical treatment, such as exercise, weight loss, and/or antiinflammatory medication

40-48 May indicate satisfactory joint function. May not require any formal treatment. 